\title{
References
}

1. Cluster (1990). Muzykalnyi entsiklopedicheskiy slovar [online]. Moscow: Sovetskaya Encyclopediya. Available at: http://www.music-dic.ru/html-music-keld/k/3214.html [Accessed 26 Jan. 2019] [in Russian].

2. Musical Encyclopedic Dictionary. (1991). Moscow: Sovetskaya Encyclopediya [in Russian].

3. Mute. Slovar inostrannykh muzykalnykh terminov [online]. Available at: https://musical_terms.academic.ru/4720/mute [Accessed 27 Jan. 2019] [in Russian].

4. Yutsevych, Y. (2009). Pizzicato. Slovnyk-dovidnyk muzychnykh terminiv [online]. Available at: http://term.in.ua/indeks.html?term=ПІЦИКАТО [Accessed 28 Jan. 2019]. [in Ukrainian].

5. Khrust, N. (2016). New instrumental techniques. Classification experience. Nauchnyy vestnik Moskovskoy konservatorii, 1 (24), pp. 125-143 [in Russian].

6. Proulx, J.-F. (2009). A pedagogical guide to extended piano techniques. Doctor of Musical Arts thesis. Philadelphia: Temple University [in English].

7. Reiko, I. (2005). The Development of extended piano techniques in twentieth-century American music. Doctor of Music thesis. Tallahassee: Florida State University College of Music [in English].

8. Smith, G. E. (2011). Performance Techniques for Four Avant-garde Piano Pieces by Henry Cowell. $\mathrm{PhD}$ thesis. Berrien Springs: Andrews University [in English].

9. Vaes, L. (2009). Extended Piano Techniques in Theory, History and Performance Practice. PhD thesis. Leiden: Leiden University [in English].

УДК 784.3.071.1:82-1:781.62(477)

DOI: https://doi.org/10.33643/kmus.2019.58.04

Анна Калініна,

здобувач кафедри історії української та зарубіжної музики, старший лаборант навчальної лабораторії історії украӥнської та зарубіжной музики Харківського начіонального університету мистецтв імені І. П. Котляревського https://orcid.org/0000-0001-6938-4194 anet0692@ukr.net

Anna Kalinina, Applicant of the Department of History of Ukrainian and Foreign Music, Senior laboratory assistant at the educational laboratory of History of Ukrainian and Foreign Music, Kharkiv National I. P. Kotlyarevsky University of Arts https://orcid.org/0000-0001-6938-4194 anet0692@ukr.net

\section{СПІВВІДНОШЕННЯ МУЗИЧНОГО ТА ПОЕТИЧНОГО РИТМУ В РАННІХ ВОКАЛЬНИХ ЦИКЛАХ ВАЛЕНТИНА БІБІКА}

Розглядаються принципи втілення віршового ритму у трьох ранніх вокальних циклах В. Бібіка - «Пісні батьківського дому», «Акварелі» та 
«Два інтермецо», які відбивають пошуки композитора власного шляху у цій жанровій сфері на ранньому етапі творчості. У першому опусі автор використовує різні типи вокалізації віршованого тексту, однак залишається у руслі традиції. Для одночастинної композиції «Акварелей» притаманні сонористичні ефекти, відмова від метричної сітки, особливі прийоми виконання, які забезпечують своєрідність ритміки вокальної партії. В «Двох інтермецо» В. Бібік розширює виконавський склад, залучаючи до традиційного дуету голосу та фортепіано ще й флейту. Цей твір постає новим етапом активних пошуків композитора у жанрі камерно-вокальної музики.

Ключові слова: пісня, романс, співвідношення музичного та поетичного ритму, ранні вокальні цикли В. Бібіка.

Kalinina Anna. The ratio of the musical and poetic rhythm in the early vocal cycles by Valentin Bibik. The principles of the embodiment of the poetic rhythm in the early vocal cycles by V. Bibik - «The Songs of the Father's House» on the verses by V. Lugovsky and O. Stewart op. 3, «The Watercolours» on the verses by A. Voloshchak op. 15, «Two Intermezzos» on the verses by G. Gdal op. 23 have been considered. They reflect the composer's search of his own way in this genre sphere. The poetic texts of the first of them are not connected by a single storyline; they are brought together by the focus on folklore genres. Combining the poetic and musical rhythm, V. Bibik uses various ways to vocalize a poetic text: in «The Restless» (No. 1) he sticks to the verse meter, sometimes emphasizing the last syllables; in «The Lullaby with Black Jackdaws» (No. 2), he relies on declamation features, focusing on the genre prototype of the verse - children's playground rhyme; in «The Wedding» (No. 3) and «The Sad» (No.4) he changes the number of stressed syllables, emphasizing the emotionality of the statement; in «The Vesnyanka Song» (No. 5) - he brings to the fore the counter rhythm.

«The Watercolours» on the verses by A. Voloshchak demonstrate the author's aspiration to go beyond the tradition, which provided a new approach to the poetic rhythm. In one case, the composer increases the number of the stressed syllables, in the other, he aligns the vocal line with quarters, which allows the poem to expand its own metre-rhythm, in the third, he changes the accents of the poetic text. Such a variety of vocalization techniques contributes to the reflection of subtle feelings, the rich semantics of poetry.

«Two intermezzos» on the verses by G. Gdal is a new step on the path of the composer's active search in the genre of chamber-vocal music. V. Bibik extends the traditional performing composition, introducing the flute, and interprets the voice as one of the instruments of the trio. The originality of the poet's poems, created in the form of vers-libre, contributes to this. On the one 
hand, the composer gives a certain freedom to the poetic rhythm, simplifying the melodic one; on the other hand, he adheres to the phrasing of the verse. The desire for liberation from the established tradition affects the author's flexible attitude towards the vocal voice, its functions in the vocal-instrumental ensemble, and the inclusion into the texture of the imitative type.

Thus, the principles of the embodiment of the poetic rhythm embodiment chosen by V. Bibik in the three early vocal cycles allow the composer to go from following the tradition to individualizing the genre.

Key words: song, romance, ratio of the musical and poetic rhythm, early vocal cycles by V. Bibik.

Калинина Анна. Соотношение музыкального и поэтического ритма в ранних вокальных циклах Валентина Бибика. Рассматриваются принципы воплощения поэтического ритма в ранних вокальных циклах В.Бибика - «Песни отчего дома» на стихи В. Луговского и О. Стюарт ор. 3, «Акварели» на стихи А. Волощака ор. 15, «Два интермеццо» на стихи Г. Гдаля ор. 23. Они отражают поиски композитора собственного пути в данной жанровой сфере. Поэтические тексты первого из них не связаны единой сюжетной линией; их сближает ориентация на фольклорные жанры. Соединяя поэтический и музыкальный ритм, В. Бибик использует различные способы вокализации стихотворного текста: в «Непокойной» (№ 1) придерживается метра стиха, иногда подчеркивая последние слоги; в «Колыбельной с черными галками» (№ 2) опирается на декламационность, ориентируясь на жанровый прототип стиха - считалку; в «Свадебной» (№ 3) и «Печальной» (№ 4) изменяет количество ударных слогов, подчеркивая эмоциональность высказывания; в «Веснянке» (№ 5) - выводит на первый план встречный ритм.

«Акварели» на стихи А. Волощака демонстрируют стремление автора выйти за пределы традиции, что обеспечило новый подход к стихотворной ритмике. В одном случае композитор увеличивает количество иктов, в другом - выравнивает вокальную линию четвертными, что позволяет стихотворению развернуть собственный метроритм, в третьем - изменяет акценты поэтического текста. Такое разнообразие приемов вокализации способствует отражению тонких чувств, богатой семантики стихов.

«Два интермеццо» на слова Г. Гдаля являются новым шагом на пути активных поисков композитора в жанре камерно-вокальной музыки. В. Бибик расширяет традиционный исполнительский состав, вводя флейту, и трактует голос как один из инструментов трио. Этому способствует своеобразие стихов поэта, созданных в форме верлибра. С одной стороны, 
композитор дает определенную свободу поэтическому ритму, упрощая мелодический, с другой - придерживается фразировки стиха. Стремление к освобождению от устоявшейся традиции влияет на гибкое отношение автора к вокальному голосу, его функциям в вокально-инструментальном ансамбле, включению в фактуру имитационного типа.

Таким образом, избранные В.Бибиком принципы воплощения поэтического ритма в трех ранних вокальных циклах позволяют композитору пройти путь от следования традиции к индивидуализации жанра.

Ключевые слова: песня, романс, соотношение музыкального и поэтического ритма, ранние вокальные циклы В. Бибика.

Постановка проблеми. Серед численних опусів у творчому добутку Валентина Савича Бібіка (1940-2003) значне місце посіли вокальні цикли для голосу 3 інструментальним супроводом. Їх вирізняє жанрове та образно-змістовне розмаїття, що відображає безперервні пошуки композитора у царині камерно-вокальної музики. Найбільш показовими у цьому плані постають ранні вокальні твори. Характеристика їх композиційно-драматургічних особливостей, музичної мови міститься в монографії, присвяченій розгляду провідних жанрів у спадщині українського митця [4]. Однак, взаємодія музичного та поетичного ритму досі залишається поза межами дослідницької думки, чим обумовлюється новизна та актуальність запропонованої теми.

Mema дослідження полягає у виявленні особливостей втілення метричної структури поетичних першоджерел у ранніх вокальних циклах В. Бібіка.

Для вирішення завдань дослідження були залучені наступні методи: історичний, жанрово-стильовий, структурно-функціональний і порівняльний.

Результати дослідження. Ранні камерно-вокальні опуси - «Пісні батьківського дому» для баса та фортепіано на вірші В. Луговського та О. Стюарт ор. 3 (1968), «Акварелі» для сопрано та фортепіано на вірші А. Волощака ор. 15 (1973), «Два інтермецо» для баса, флейти та фортепіано на вірші Г.Гдаля ор. 23 (1975), відбивають пошуки композитора власного шляху у даній жанровій сфері. Вони відрізняються за змістом першоджерел, принципами їх втілення, структурними особливостями романсів. Щоб підтвердити вищесказане, окреслимо еволюційні процеси у мелодиці вокальної партії, розкриті авторами монографії, присвяченої композитору. Для першого циклу характерні сталі типи мелодії: речитація, декламація, пісенність тощо. У вокальній партії «Акварелей» композитор проникає «в тонкощі фольклорної інтонації та 
манери співу» [4, с. 82], що надана в опосередкованому вигляді. У «Двох інтермецо» проявилася «нон-кантиленна природа музичного матеріалу», яка позбавила вокальну мелодію «теплоти та об'ємності, співучості та широти дихання <..>» $[4$, с. 81$]$.

Незважаючи на постійне оновлення музично-мовних засобів та звернення до різної за стилем поезії, В. Бібік обирає близькі йому образи, наповнені натхненними пейзажами, інтимними ліричними переживаннями, що часто сягають своїм корінням до фольклорних витоків. Охарактеризуємо передусім поетичні першоджерела 3 метою підтвердження художньо-естетичних переваг композитора. П'ять віршів, обраних для «Пісень батьківського дому» ${ }^{1}$, не пов'язані єдиною сюжетною лінією: кожен 3 них має власний семантичний ряд та емоційне забарвлення. Водночас, їх зближає орієнтація на фольклорні жанри, заявлені як у назвах ${ }^{2}$, так і у змісті творів. Інакше кажучи, хоча вірші не належать одному поету та різняться за образним змістом, вони складають органічну композицію, побудовану за принципом контрасту. «Неспокійна» (№ 1) слугує своєрідною передмовою до всієї композиції. В іiі образносмисловому наповненні виділяються два взаємопов'язані між собою плани: зовнішній - відтворює пейзаж похмурої, безпросвітної ночі, та внутрішній - передає почуття та переживання, викликані навколишньою обстановкою. За формою вірш наближається до верлібру: його основу складає ямб, який в деяких рядках змінюється хореєм, при цьому кількість наголошених складів постійно варіюється ${ }^{3}$. Як приклад наведемо першу строфу вірша в перекладі В. Грінчака:

\section{Дуби шумлять, дуби шумлять, \\ Всю ніч осінню шелестять. \\ Туман лежить полотнами, \\ Над річкою холодною лежить.}

У серцевині вокального циклу розміщені вірші, що за тематикою нагадують своєрідний «триптих» родинно-обрядових пісень: колискова, весільна та плач. Якщо перші два жанри більш наближені до фольклорних

\footnotetext{
${ }^{1}$ Більшість із них належить В. Луговському - «Неспокійна» (№ 1), «Колискова 3 чорними галками» (№ 2), «Весільна» (№ 3) та «Веснянка» (№ 5), один - «Печальна» (№ 4) - О. Стюарт.

2 Зауважимо, що жанр «пісні», зазначений автором у назві вокального циклу, підкреслюється у найменуваннях кожної вокальної мініатюри.

${ }^{3}$ Доцільно нагадати, що на відміну від класичного силабо-тонічного вірша 3 системою обов'язкових повторів, рівномірним чергуванням наголошених та ненаголошених складів, точною римою, верлібр відзначається настановою «на неперіодичну та нічім не обмежену зміну мір повтору» [2, с. 710].
} 
зразків, то останній - співпадає лиже за образним змістом, оскільки представлений як сумна розповідь від третьої особи, відсторонений погляд. «Колискова 3 чорними галками» (№ 2) В. Луговського позбавлена характерних для свого фольклорного орієнтиру рис та виходить за межі заявленого жанру, оскільки, як справедливо зауважують науковці, iii прототипом постає лічилка [4, с. 126]. Водночас А. Іваницький говорить, що колискові пісні мають досить широкий тематичний діапазон, а їх основою можуть стати «лічилки, баладні, навіть жартівливі пісні із “дорослого" репертуару» [3, с. 17]. Таким чином, даний твір має два жанрові витоки. 3 одного боку, образно-смислове наповнення відповідає колисковій, про що свідчать вирази - «А ти, рідна, міцно спи, а сніжок лети», «Сон торкнувсь очей і скронь, а в печі горить огонь»; характерні «замовляння» доброї долі та відлякування біди, котрі мають магічне призначення, - «щастя буде, неодмінно буде, нас $з$ тобою щастя не забуде», «геть, бідо, з життя мого» тощо. 3 іншого боку, ритміка віршових рядків відповідає жанру лічилки, що проявляється у використанні нерівностопних рядків та, у деяких випадках, зміні поетичного метру задля збереження рівномірного чергування іктових та ненаголошених складів. Окрім цього, для «Колискової» притаманний нерівномірний ритм, який виникає завдяки пришвидшенню промовляння окремих виразів та слугує для збереження метричного пульсу. Звернемо увагу на ритмічний малюнок перших двох рядків четвертої строфи, виражених схематично у музичному ритмі:

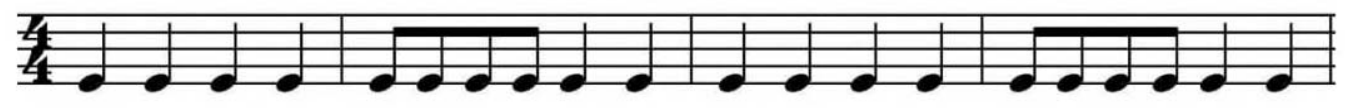

Роз_гу_ля_лась ві_хо_ла в до_ли_ні, зак_віт_ча_лась сві_роч_ка - яли_на

Поетичне першоджерело третього романсу - «Весільна» (№ 3), за принципом викладення образного змісту нагадує «Неспокійну», оскільки включає два семантичні плани: неперевершений зимовий пейзаж, на тлі якого розгортається весільне святкування, проносяться прикрашені сани, лунає веселий сміх ${ }^{1}$. Відповідно до цього поетичний текст розподіляється на дві частини: перша половина присвячена образам природи, друга радісним, ніжним почуттям, викликаним головною подією у житті молодих ${ }^{2}$. Тим більшим контрастом сприймається вірш «Печальної» (№ 4) на слова О. Стюарт. Він постає як «скорботний монолог від третьої особи», що «просто та невигадливо оповідає про материнську втрату» [4,

\footnotetext{
${ }^{1}$ Як зазначають науковці, вірш рясніє «характерними для даної тематики образами снігу, морозу, трійки, що мчиться, дівочою піснею» [4, с. 79].

2 Загальна його будова $\epsilon$ класичною: шість чотирирядкових строф 3 поетичним метром - хореєм.
} 
с. 80]. Попри це у творі наявні декілька персонажів та немовби пряма мова. Замикає вокальну композицію лірична «Веснянка», що розповідає про кохання до юної красуні. Образний зміст вірша відсилає до календарно-обрядових пісень весняного циклу, а точніше - русальних, про що свідчить наявність образу русалок. Вірш має досить вільну метричну схему, засновану на тридольних стопах, котрі наприкінці кожного рядка змінюються дводольними. Це надає тексту особливої ліричності, ніжності, вальсової легкості.

Вірші А. Волощака 3 вокального циклу «Акварелі» на перший план виводять лінію тонкої, зворушливої пейзажної лірики, заявлену в «Піснях батьківського дому». Їх образно-смисловий ряд містить сприйняття природи у просторово-часовому аспекті, що викликає безпосередні асоціації 3 мальовничими картинами художників-імпресіоністів. Поетична композиція складається 3 трьох різних за метричною структурою розділів ${ }^{1}$. Перший описує ласкавий світанок у лісах, коли сонце повсюди протягує перші теплі промені, від яких просинаються дерева, вітер, тінь. Другий розділ постає логічним продовженням першого: сонце вже піднялось досить високо, щоб освітити все навколо. Третій - присвячений могутньому сяйву сонячного світила, котре наближається до горизонту. Завершується віршований текст невеликою кодою-колисковою: «Люлі-люль, люлі лю... Люба коханочко, злата паняночко, лю... Люблю, я донечку, мов ясне сонечко. Ой люлі, лю...». Зауважимо, що серед багатьох троп у вірші А. Волощака найбільшого значення набуває персоніфікація, оскільки кожне природне явище представлене як персонаж, що виконує різні дії: «стоять задумано ліси», «трави мов проснулись, шепочуть», «земля всміхнулась», «сонце хоче застелити», «лестки беріз тремтять, колишуть тишу» і багато іншого. Завдяки цьому поетичний текст набуває тендітності та теплоти.

Своєрідним продовженням «Акварелей» в образному сенсі постають вірші Г. Гдаля з «Двох інтермецо» В. Бібіка, оскільки втілюють характерні для ліричної поезії картини природи, сповнені тонких, ніжних почуттів. Перший 3 них описує пейзаж ніжного, прозорого ранку. Емоційність висловлювання посилюють пестливі слова та образ срібної росинки, котра бачила сон про «велике багряне сонце». Другий вірш поєднує пейзажну та інтимну лірику: через образи природи поет відтворює дівочу красу коханої, порівнюючи іiі з березою, полохливим дощем, легким подивом вітру, теплим подихом сонця тощо. Зауважимо, що такий принцип втілення образного змісту надає віршу фольклорних рис.

\footnotetext{
${ }^{1}$ Крайні частини написані ямбом, середня - хореєм.
} 
Незважаючи на певні паралелі між віршами, все ж їх композиційноструктурне різноманіття та прагнення композитора до оновлення музичномовних засобів сприяло індивідуалізації вокальних циклів, зокрема принципів втілення віршового ритму. Хоча «Пісні батьківського дому» знаходяться у руслі традиції та, за визначенням науковців, відсилають «до досвіду Мусоргського» [4; с. 78], для кожного романсу В. Бібік обирає власні прийоми вокалізації поетичного тексту. У першому з них автор здебільшого зберігає поетичні акценти, іноді посилюючи останні склади виразів задля виокремлення важливих семантичних одиниць та підкреслення завершеності висловлювання. Прикладом слугують наступні слова та вирази: «триВОЖНИЙ», «нічНОго ВІТРУ», «для ТЕБЕ ЧАрів $C B I T У_{\gg}$. Виходячи $з$ цього, пануючим типом вокалізації в даному романсі постає метричний. Разом з тим, акцентуванню сприяє не тільки відповідна пульсація, а й квантитативність, тобто посилення більш довгою тривалістю $[5$, c. 22], що нагадує античний вірш, де наголоси утворювалися за допомогою зміни довгих та коротких складів. Тридольний розмір романсу $(12 / 8,9 / 8)$ не надає звучанню вокальної партії танцювальності, оскільки призначення для тембру басового голосу та стриманий темп (Molto sostenuto) створюють обтяжуючий ефект, змальовуючи пейзаж таємничої, похмурої ночі. У вокальній мелодії «Колискової з чорними галками» (№ 2), відповідно до змісту, зіштовхується ритм двох жанрових прототипів романсу - колискової та лічилки. На початку твору В. Бібік спирається на речитативно-декламаційний тип ритміки. Орієнтиром для нього є не прозаїчна мова, а віршований текст: ритм лічилки стає провідним для відображення поетичного першоджерела, що надає звучанню чіткої метричної пульсації, енергійності, рухливості. Влучним прикладом слід назвати ритміку вокальної партії перших двох строф, яка майже точно відповідає мовленнєвій, за виключенням декількох розспівів. Поступово кількість останніх значно збільшується, 3'являються протягнуті звуки довгими тривалостями. Це свідчить щодо посилення ролі кантиленності, котра нагадує про первинний жанр твору - колискову. Найбільший прояв це отримує у місцях з відповідним змістом: вираз «А ти, рідна, міцно спи» повністю побудований на розспівах.

Незважаючи на те, що «Весільна» (№ 3) та «Печальна» (№ 4) репрезентують афективні «полюси» - безмежна радість від народження нової сім’ї та трагедія втрати останнього сина старенькою матусею, - все ж відбиття віршованого тексту в них має спільні риси. Композитор змінює кількість наголошених складів задля посилення емоційності висловлювання. У «Весільній» проявляється тенденція до збільшення 
акцентів: додаткові ікти отримують вирази «НА тоПОЛІ ІНІЙ ЛІГ», «ЗАдиВИЛИСЬ У ПОЛЯ», «ЧАРІВНІ ПІСНІ ВКРАЇНИ», «дзвінКИЙ ВЕЧІРНІЙ ЧАС», «ПО заСНІЖЕНИМ СЛІДАМ». Таким способом В. Бібік виділяє у тексті важливі образно-смислові одиниці, додає виразам вагомості, піднесеності висловлювання. Завдяки цьому вокальна мелодія даного романсу набуває пісенних рис зі значним включенням кантиленних розспівів. У романсі «Печальна», навпаки, кількість акцентів істотно зменшується, на перший план виходить скандування та речитація. Вокальна лінія нерідко вирівнюється восьмими тривалостями, що в розмірі 4/4 призводить до нівелювання більшості хореїчних наголосів: «ПРОчитала ТА й заголоСИла: ОЙ немає ВЖЕ мойх сиНІВ. ЧАЙкою поЛИнула в миНУле, ЗГАдуючи РІдні береГИ». У цих рядках акценти відповідають мовленнєвим, що сприяє виникненню речитативнодекламаційного типу мелодії, який справляє великий емоційнопсихологічний вплив на слухача.

У «Веснянці» (№ 5) автор значною мірою переосмислює поетичний метр. Тут панівне місце займає зустрічний ритм, який реалізується за допомогою синкоп, розспівів. Акценти віршованого тексту не просто збільшуються чи зменшуються, а інколи й змінюють своє положення так, що безударні склади стають іктовими і навпаки:

\section{За горами Уралу сивими}

L_—I_L_——I Крановщиця жила красунечка.

$1 \_1-1 \_-1$

Подібне переакцентування у купі з синкопованим танцювальним супроводом надає висловлюванню надзвичайної легкості, тендітності, грайливості. Таким чином, у цьому циклі композитор досить вільно відноситься до музичного втілення поетичного ритму задля відбиття всіх тонкощів поетичного змісту, хоча в цілому залишається в межах сталих принципів вокалізації тексту.

«Акварелі» на вірші А. Волощака (1973) демонструють прагнення митця вийти за межі традиції, що заявлено на різних композиційних рівнях. На думку авторів монографії, вони відрізняються «сонорноколористичним звучанням музики та обіграванням ритмофонічної сторони поетичного тексту, що наближає їх до інструментальної мініатюри прелюдійного типу» [4, с. 82]. Таке спостереження підтверджується й на структурному рівні, оскільки при жанровому позначенні «вокальний цикл» В. Бібік створює одночастинну композицію, розділи якої, немов акварельні 
фарби, змішуються, перетікають один в інший ${ }^{1}$. При втіленні віршового ритму композитор проявляє велику винахідливість, застосовує різноманітні прийоми. Насамперед звертає на себе увагу відсутність чіткої метричної сітки. На початку твору музичний розмір загалом не виставляється, а кількість доль такту є довільною; надалі з'являються розміри $7 / 4,11 / 4,6 / 4,12 / 4,14 / 4,16 / 4$ тощо. В. Холопова визначає такий метроритм як «систему вільноперемінного такту», що «виражається як у чисельнику, так і знаменнику дробу тактового розміру» [4, с. 26]. Таке оновлення музичної метрики зумовило й новий підхід до втілення ритміки віршованого тексту. В деяких випадках композитор значно збільшує кількість іктів (іноді майже кожний склад наголошується завдяки подовженню звучання чи розспіву), в інших - він вирівнює вокальну лінію четвертними, що за умов «вільноперемінного такту» наче дозволяє віршові розгорнути власний метроритм, підтриманий лише мелодичними акцентами. Перший прийом нерідко використовується для змалювання пейзажу, милування красою та величчю природи, тобто у строфах 3 перевагою описовості. Наприклад, майже усі склади акцентуються у виразах «стоять задумано ліси», «хор веселих сонячних іскор», «та до сонця〉 та у першій половині шостої строфи, де наданий опис могутнього сяйва сонця, що покидає небесні простори. Другий прийом вокалізації поетичного тексту більшою мірою слугує для відображення рухових, дійових строф. Окрім цього, композитор іноді повністю переакцентовує поетичний текст так, що це допомагає виокремити певні смислообрази: «СОНие хоЧЕ ЗАстелиТИ НІЖним квіТОМ, біЛИМ шовКОМ-окСАмиТОМ КОЖНУ СТЕЖКУ». ОТже, своєрідні прийоми вокалізації у даному вокальному творі сприяють втіленню тонких відчуттів, багатої семантики поетичного тексту.

У «Двох інтермецо» на слова Г. Гдаля (1975) В. Бібік розширює виконавський склад, залучаючи до традиційного дуету голосу та фортепіано ще й флейту. Твір постає новим кроком на шляху активних пошуків композитора у жанрі камерно-вокальної музики². Новаторський характер віршів Г. Гдаля, написаних у формі верлібру, відповідав прагненням митця. Відсутність будь-якої рими сприяе новій трактовці його можливостей. 3 одного боку, В. Бібік дає певну свободу поетичному ритму, спрощуючи

\footnotetext{
${ }^{1}$ Музикознавці наголошують, що композитор «мислить ціле як своєрідну мозаїку яскравих лаконічних епізодів, зчеплення яких створює тричастинну форму з активною, багатоетапною динамічною серединою» [4, с. 82].

${ }^{2}$ Автори монографії зазначають, що композитор «ніби пориває зі сформованою пісенно-романсовою традицією, трактуючи голос як один з інструментів своєрідного тріо» [там само, с. 81].
} 
мелодичний, з другого - дотримується фразування вірша. У цьому сенсі даний цикл виявляє певні паралелі 3 «Акварелями», що посилюється відмовою від музичного розміру. Таким чином, вокальна партія «Двох інтермецо» поєднує риси метричного (за рахунок використання рівномірних тривалостей) та речитативно-декламаційного (відповідно до мелодичних акцентів) принципів вокалізації поетичного тексту. Окрім цього композитор застосовує особливі прийоми виконання, серед яких ритмодекламація, проговорювання тексту. Аналогічний спосіб роботи з поетичним текстом, наближення його вокальної ліній до інтонаційності вірша отримує розвиток й у подальшій камерно-вокальній творчості митця. За спостереженнями Т. Вєркіної, у циклі «Завітнійше» (1986) вибір «вокального амплуа й характер інтонування визначалися тим, як промовляла вірші сама А. А. Ахматова» [1, c. 13]. Однак, зазначений спосіб вокалізації ще повною мірою не розкривається у «Двох інтермецо», оскільки партія вокаліста в ньому завдяки мовним засобам наближена до інструментальної, що призводить до зміни принципів побудови багатоголосної музичної тканини, застосування можливостей поліфонічного складу. У першій частині вокального циклу партії сполучаються на контрапунктичній основі. Це посилюється й тим, що для фортепіанної партії замість звичних двох нотних станів відведено тільки один. Інакше кажучи, кожен з трьох голосів ансамблю індивідуалізований в інтонаційно-ритмічному плані. Друга ж частина заснована на іншому типі поліфонії - вона представлена як чотириголосна імітаційна п’єса.

Висновки. Три ранні вокальні цикли постають показниками пошуків В. Бібіка індивідуальних підходів до втілення ритміки поетичних творів. Дотримуючись образно-смислового ряду останніх, композитор поширює стилістичні засоби, які впливають на принципи співвідношення музичного та поетичного ритму. Вже у «Піснях батьківського дому» автор досить вільно оперує віршовими розмірами, застосовуючи різні прийоми вокалізації, серед яких панівне місце посіли метричність та декламаційність. Відмова від сталого музичного розміру в «Акварелях» утворює великий простір для роботи 3 ритмікою вірша: композитор спирається на декламаційність (рівномірний рух четвертними) та зустрічний ритм (розспіви, подовження звуку довгою тривалістю). Ритмізація вокальної партії «Двох інтермецо» обумовлена, з одного боку, свободою метричної структури верлібру, а 3 другого - включенням вокального голосу до фактури поліфонічного типу. Інакше кажучи, при збереженні смислових акцентів поетичного тексту в ритмічному малюнку вокальної партії переважає рух рівномірними тривалостями. 
1. Вєркіна Т. Б. Актуальне інтонування як виконавська проблема : автореф. дис. ... канд. мистецтвознавства : 17.00.03. Київ, 2008. 20 с.

2. Жовтис А. Л. Свободный стих// Краткая литературная энциклопедия / гл. ред. А. А. Сурков. Т. 6. Москва, 1971. Стб. 709-711.

3. Іваницький А. I. Український музичний фольклор : підруч. для вищих навч. закладів. Вінниця : Нова книга, 2004. 320 с.

4. Мизитова А., Иванова И. Фрагменты творчества Валентина Бибика: монограф. очерки. Харьков, 2006. 126 с.

5. Ручьевская Е. Слово и музыка // Анализ вокальных произведений : учеб. пособие / отв. ред. О. П. Коловский. Москва, 1988. С. 5-80.

6. Холопова В. Ритмика Э. В. Денисова // Музыка Эдисона Денисова. Москва, 1995. C. 24-39.

\section{References}

1. Verkina, T. (2008). Actual intonation as the performing problem. Extended abstract of $\mathrm{PhD}$ thesis. Kyiv [in Ukrainian].

2. Zhovtis, A. (1971). Free verse. Kratkaya literaturnaya entsiklopediya. A. Surkov (Ed.). Moscow [in Russian].

3. Ivanyczkyj, A. (2004). Ukrainian folk music. Vinnytsa: Nova knyga [in Ukrainian].

4. Mizitova, A., Ivanova, I. (2006). Fragments of Valentine Bibik's creative work. Kharkiv [in Ukrainian].

5. Ruchievskaya, E. (1988). Word and music. In: Analysis of vocal works. O. Kolovskiy (Ed.). Moscow [in Russian].

6. Holopova, V. (1995). Rhythmic by E. V. Denisov. In: Music by Edison Denisov. Moscow [in Russian].

УДК 781.7:78.087+78.071(477) Загайкевич

DOI: https://doi.org/10.33643/kmus.2019.58.05

Олена Лис,

викладач кафедри музично-теоретичних дисииплін Київької муніципальної академії естрадного і ииркового мистецтв https://orcid.org/0000-0001-8375-8527 olenalys@ukr.net

Olena Lys, Lecturer of the Chair of musical and theoretical disciplines, Kyiv Municipal Academy of Variety and Circus Arts https://orcid.org/0000-0001-8375-8527 olenalys@ukr.net

\section{РОЛЬ ФАКТУРНОЇ ДИНАМІКИ ТА ЇЇ КОМПОНЕНТІВ У СТРУННОМУ КВАРТЕТІ АЛЛИ ЗАГАЙКЕВИЧ}

У статті на прикладі струнного квартету А. Загайкевич розглядається феномен музичної фактури як явище динамічне, багатогранне, пов'язане 3 